\title{
SENTIMEN BISNIS DAN KONSUMEN DALAM SIKLUS EKONOMI INDONESIA
}

\author{
Taufik Akbar \\ Universitas Islam Kadiri \\ taufikakbar@uniska-kediri.ac.id \\ Edi Murdiyanto \\ Universitas Islam Kadiri \\ edimurdiyanto@uniska-kediri.ac.id \\ Anita Sumelvia Dewi \\ Universitas Islam Kadiri \\ anita@uniska-kediri.ac.id
}

\begin{abstract}
This research aims to find out the relationship between consumer confidence, business confidence, consumer price index, and composite stock price index in Indonesia because the indicator describes a country's economic cycle as a result of sentiment that occurs. Quantitative descriptive research using multivariate methods of cointegration and granger causality within the VECM statistical framework. The period of the study is from 2015 2020. VECM estimation shows that in the long term there is a positive relationship pattern between CCI and itself. Then PMI shows a pattern of positive relationships, while CPI and JCI show negative relationships. Only PMI variables have a significant effect on the CCI in the long run. Then in the short term, PMI has a positive relationship pattern and has a significant influence on CCI and JCI in lags 1 and 2, and has a significant influence on CPI in lag 2. JCI has a positive and significant relationship pattern to CCI and CPI in lag 2. This research still does not discuss the dynamic behavior of the VECM model through the response of each variable to the shock of other variables and forecasting how the response of a variable in the future if a shock occurs in other variables. Governments and central banks must be able to reduce market panic and build a level of public trust. It can be said that optimism from the point of view of the business world and consumers needs to be maintained by stakeholders, especially governments and central banks.
\end{abstract}

Keywords: business confidence; consumer confidence; sentiment; VECM.

\section{PENDAHULUAN}

Consumer confidence dan business confidence adalah indikator krusial yang digunakan dalam melihat gambaran siklus bisnis dan perekonomian. Ketika suatu negara mengalami gejolak dalam perekonomiannya, proses dalam mengembalikan tingkat kepercayaan menjadi hal yang sangat penting dibanding waktu normal. Consumer confidence index (CCI) adalah salah satu variabel yang berpengaruh dalam menggambarkan keputusan konsumsi suatu situasi ekonomi (Bock et al., 2014; Soric, 2018) dan juga merefleksikan derajat optimisme secara umum serta 
relevan digunakan dalam meramalkan kondisi ekonomi (Kilic and Cankaya, 2016; Soric 2018). Selain itu tingkat keyakinan dunia usaha yang diproksikan dalam Purchasing Manager's Index (PMI) juga menjadi tolak ukur kondisi manufaktur suatu negara. Apakah sektor manufaktur banyak melakukan aktivitas pembelian yang nantinya berpengaruh pada output, tentu kondisi tersebut tergambar dalam indeks tersebut.

Perilaku konsumsi adalah bagian turunan dari kebijakan makroekonomi yang bersifat jangka pendek dan jangka panjang. Hal ini terjadi karena dua alasan; yang pertama, konsumsi membentuk siklus bisnis yang mana hal ini mempengaruhi kebijakan moneter yang bersifat jangka pendek. Yang kedua, keputusan untuk melakukan konsumsi menentukan levels of saving dan harga saham, tingkat suku bunga, tingkat upah, dan kesejahteraan dalam jangka panjang yang pada akhirnya mempengaruhi kebijakan fiskal dan moneter (lyke and Ho, 2019). Dalam studi lain yang dilakukan oleh Juhro (2015), yang menekankan pentingnya konsumsi sebagai pendorong utama pertumbuhan ekonomi di negara berkembang, seperti di Indonesia. Pasca terjadinya krisis keuangan global, pertumbuhan ekonomi Indonesia didorong oleh konsumsi. Konsumsi menyumbang sekitar 60\% dari pertumbuan produk domestik bruto di Indonesia pasca krisis keuangan global (Juhro, 2015). Efek positif daripada consumer confidence diharapkan mampu mengurangi resiko tingginya saving rate, sehingga dapat mendorong consumer spending yang pada gilirannya akan menopang permintaan domestik dan menjaga atau justru meningkatkan pertumbuhan ekonomi jangka pendek. Senada dengan hal tersebut, adanya perbaikan business confidence akan cenderung memacu investment spending yang berkelanjutan serta mempengaruhi keputusan manajerial perusahaan terkait bisnisnya (Konstantinou and Tagkalakis, 2011).

Konsumsi sebagai barometer apakah kondisi ekonomi suatu negara mengalami kelesuan atau menggeliat. Tingat inflasi yang rendah dan ke arah negatif, menunjukkan bahwa kondisi pasar yang sedang lesu akibat dari turunnya permintaan barang dan jasa, baik itu dari sektor rumah tangga atau sektor industri. Selain itu, tingkat konsumsi yang melemah akan memicu adanya penurunan tingkat produksi, input, penurunan pendapatan, yang akhirnya akan meningkatkan jumlah pengangguran dan sebagainya (lyke and Ho, 2019). Tentunya kondisi seperti itu akan membuat situasi ekonomi menjadi tidak stabil, apalagi dimata para investor. Prospek ekonomi suatu negara menjadi perhatian khusus bagi para penanam modal. Ketika ada sentimen, tentu akan berpengaruh pada kondisi indeks harga saham. Para investor tertarik untuk mengamati bagaimana tren makroekonomi memberikan sinyal adanya perubahan dalam profitabilitas bisnis yang berimbas pada harga saham. Atas dasar inilah peneliti tertarik untuk menelaah hubungan antara tingkat kepercayaan konsumen dan bisnis, serta indikator lain yang menggambarkan aktivitas ekonomi di Indonesia. Hal ini menjadi sangat penting karena indeks yang menjadi indikator dalam penelitian ini menjadi dasar dalam proyeksi kondisi ekonomi, pembuatan kebijakan, dan rencana bisnis. 
Konstantinou dan Tagkalakis (2011) melakukan penelitian yang bertujuan untuk menginvestigasi apakah kebijakan fiskal mampu memacu consumer dan business confidence. Dalam penelitiannya dikatakan bahwa kebijakan fiskal tersebut secara luas mampu menstimulasi private spending dan aktivitas ekonomi yang berkelanjutan. Dees (2017) mengidentifikasi efek kausalitas antara confidence shocks terhadap aktivitas ekonomi riil pada beberapa negara maju. Dengan menggunakan model VAR, hasil menunjukkan bahwa guncangan tersebut memiliki dampak yang signifikan dan terus menerus pada konsumsi domestik dan PDB riil, serta menjelaskan sebagian besar perkiraan varian kesalahan dari aktivitas ekonomi riil. Pada saat yang sama, guncangan tersebut secara signifikan juga berkorelasi antar negara.

Penelitian lain yang dihubungkan dengan pasar modal diantaranya penelitian dari Zorio-Grima dan Merello (2020) yang menganalisis hubungan kausalitas antara consumer confidence dan ekosistem informasi ekonomi dari sumber subjektif (sentimen bisnis) dan sumber objektif (laporan keuangan dari perusahaan go public dan indeks saham). Hasil penelitiannya menunjukkan bahwa consumer confidence dan informasi ekonomi memberikan hubungan kausalitas satu sama lain. MØller et al. (2014) mengkaji consumer confidence dan siklus bisnis yang terjadi di Eropa. Dari hasil kajiannya ditemukan bahwa consumer confidence dan output gap mempunyai korelasi positif, dan keduanya mempengaruhi return saham. Juhro dan lyke (2019) mengestimasi consumer dan business confidence indexes, konsumsi, dan standard predictors konsumsi, yaitu pendapatan, harga saham, dan suku bunga. Dari hasil penelitiannya ditunjukkan bahwa pentingnya peran sentimen bisnis dan konsumen sebagai predictor belanja konsumsi. Peran tingkat kepercayaan dan sentimen terhadap konsumsi dan siklus bisnis mempunyai implikasi yang penting bagi Bank Sentral dalam membuat strategi kedepan untuk memelihara atau meningkatkan public/market confidence.

\section{KAJIAN PUSTAKA}

Menurut survei konsumen yang dilakukan oleh Bank Indonesia (www.bi.go.id), Indeks Keyakinan Konsumen (CCI) adalah rata-rata sederhana dari Indeks Kondisi Ekonomi saat ini dan Indeks Ekspektasi Konsumen. Indeks Kondisi Ekonomi saat ini meliputi keyakinan konsumen mengenai penghasilan saat ini, pembelian durable goods, dan ketersediaan lapangan kerja, dengan membandingkan antara kondisi saat ini dan enam bulan yang lalu. Sedangkan Indeks Ekspektasi Konsumen meliputi keyakinan konsumen mengenai ekspektasi konsumen terhadap kondisi perekonomian enam bulan yang akan datang dibanding saat ini, yang mencakup ekspektasi penghasilan, kondisi ekonomi secara umum, dan ketersediaan lapangan kerja. Indeks kepercayaan konsumen didasarkan pada persepsi konsumen tentang situasi ekonomi negara saat ini dan masa depan, kecenderungan konsumen untuk melakukan aktivitas belanja, dan kondisi dunia usaha (Ferrer et al., 2016; Salhin et al., 2016; Li et al., 2017). Kinerja perekonomian suatu negara tercermin 
dari variabel makro ekonomi seperti GNP, foreign debt, interest rate, kurs, eksporimpor, pasar modal, tingkat inflasi, upah riil, unemployment, dan seterusnya. Keadaan ekonomi juga tercermin dari perilaku mikro konsumen. Sikap dan perilaku konsumen individu mempengaruhi kinerja perekonomian. Sebagai contoh, jika konsumen yakin bahwa perekonomian sedang menuju ke arah tertentu, maka konsumen akan menyesuaikan rencana tabungan dan pengeluaran mereka.

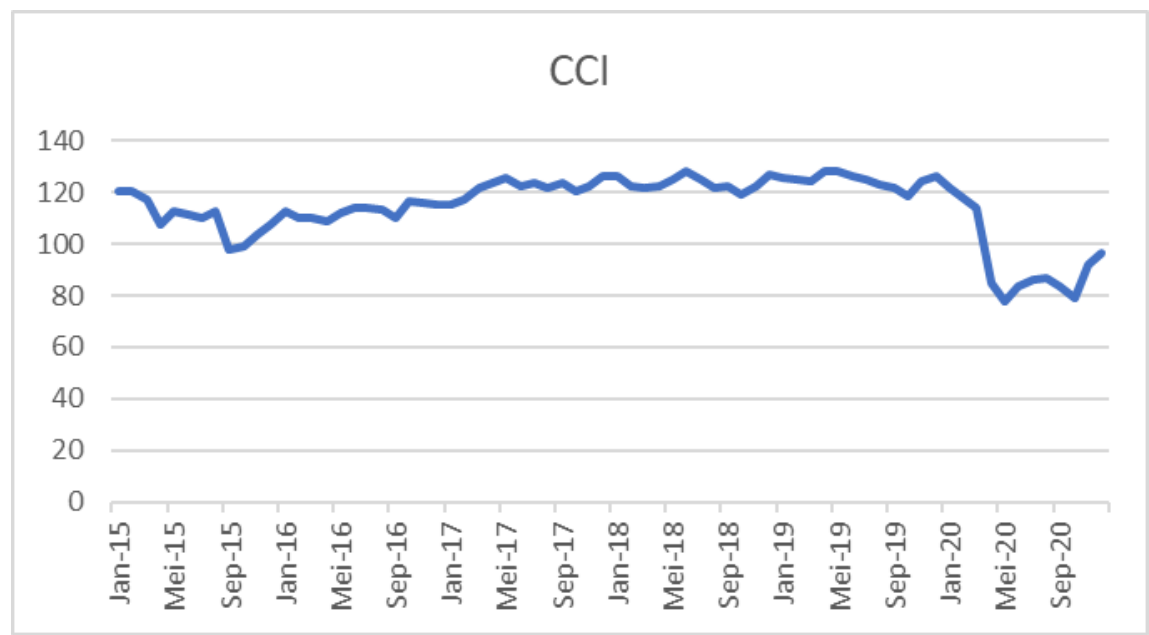

Sumber: Data diolah peneliti

Gambar 1. Consumer Confidence Index Indonesia

The Purchasing Manager's Index (PMI) adalah indikator yang mengindikasikan seberapa optimis dunia bisnis terhadap perekonomian dimasa yang akan datang. Data utama yang menjadi ukuran rata-rata pembentuk PMI adalah permintaan baru $(30 \%)$, output $(25 \%)$, ketenagakerjaan $(20 \%)$, waktu pengiriman dari pemasok (15\%), dan stok pembelian (10\%) (Anthony Joseph et al., 2011). PMI merupakan indeks yang bersifat subjektif berdasarkan laporan dari manajer pembelian perusahaan-perusahaan manufaktur disuatu negara. Beberapa manfaat dari indeks tersebut meliputi timeliness, reliability, dan prediktor dari perubahann produksi industri, produk domestik bruto riil, persediaan riil, penjualan riil, rasio penjualan atau inventaris, tingkat suku bunga bank sentral, return valuta asing, dan kebijakan moneter (Neely \& Dey, 2010., Ozyldirim et al., 2010., Berge \& Jorda, 2011., Anthony Joseph et al., 2011). 


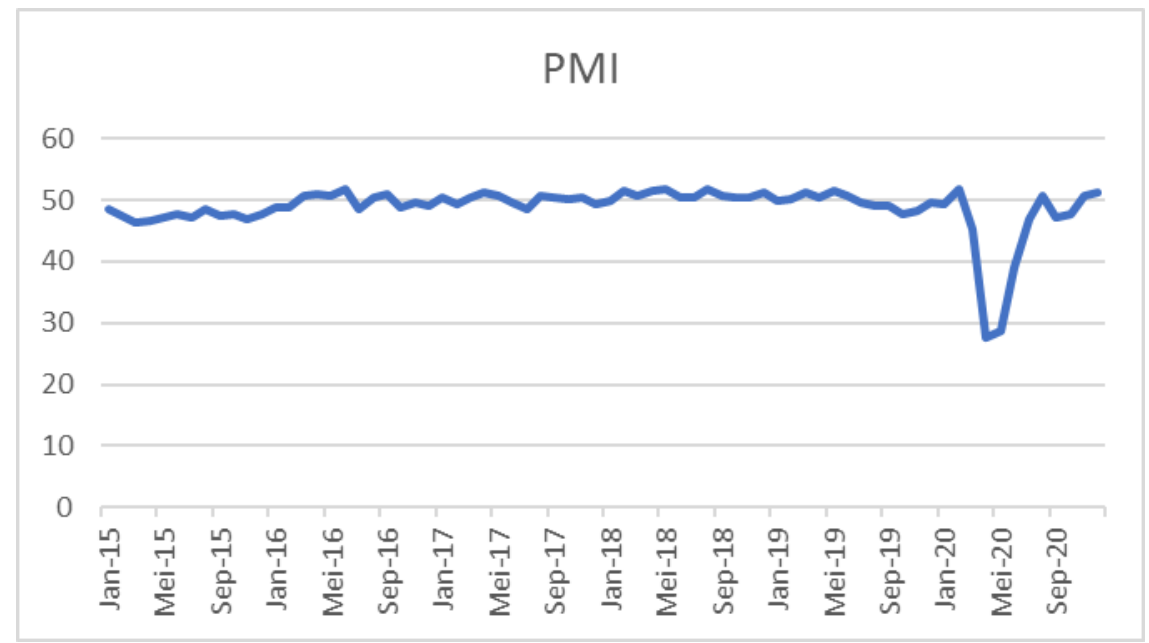

Sumber: Data diolah peneliti

\section{Gambar 2. The Purchasing Manager's Index Indonesia}

Ada sebuah literatur komprehensif yang menunjukkan bahwa inflasi bukan sekedar fenomena moneter yang mencerminkan kuantitas uang per unit output, tetapi juga mempengaruhi pasar saham, sehingga memainkan peran penting dalam menghubungan antara kebijakan moneter dan pasar saham (Suhaibu et al., 2017). Ada beberapa penjelasan teoritis mengenai kemungkinan hubungan antara inflasi dan harga saham. Tingkat pengembalian harga saham dapat mempengaruhi inflasi melalui efek mediasi yang dalam hal ini adalah konsumsi. Semisal ketika harga saham turun, investor merasa kekayaannya berkurang, sehingga mengurangi pengeluarannya dan menurunkan tekanan inflasi. Selain itu untuk kasus saham yang dijadikan jaminan, penurunan harga saham mengurangi kapasitas pinjaman yang dapat membatasi aktivitas ekonomi dan berakibat pada penurunan inflasi (Antonakakis et al., 2017). Naik dan Padhi (2012) melakukan penelitian pada pasar india selama periode 1994-2011 dan melaporkan bahwa terdapat hubungan negatif antara inflasi dan indeks harga saham. Akbar, Ali, dan Khan (2012) juga melaporkan adanya kointegrasi dan hubungan negatif pada kasus indeks saham Karachi periode 1999-2008. Hal yang berbeda ditunjukkan oleh Asmy, Rohilina, Hassama, dan Fouad (2010), yang mana dalam penelitiannya menunjukkan hubungan positif antara inflasi dan harga saham, tetapi tidak menemukan adanya hubungan kausalitas dalam konteks pasar Malaysia. Bai dan Green (2011), Alam (2017) juga melaporkan hubungan positif dalam penelitiannya. Sedangkan penelitian yang dilakukan oleh Kolluri dan Wahab (2008) pada studi kasus Amerika, melaporkan ada hubungan positif selama periode inflasi yang tinggi, namun menunjukkan hubungan negatif selama periode inflasi rendah. Antonakakis et al. (2017) juga melaporkan hubungan positif dan negatif signifikan dalam berbagai waktu pada periode 1791-2015 di Amerika. Al-Shami dan Ibrahim (2013) pada studi kasus di Kuwait menunjukkan hasil bahwa inflasi akan memicu terjadinya kenaikan harga saham setelah satu bulan, dan akan menurunkan harga 
saham setelah dua bulan. Sensitivitas harga saham dengan inflasi yang berasal dari luar negeri juga dimungkinkan terjadi, seperti penelitian yang dilakukan oleh Balcilar, Cakan, dan Gupta (2017) yang melaporkan bahwa selama periode 19942014 harga saham di pasar Asia dipengaruhi oleh berita tingkat inflasi di Amerika Serikat.

\section{METODE PENELITIAN}

Penelitian ini menggunakan metode kuantitatif, yang mana peneliti akan menelaah hubungan indeks keyakinan konsumen (CCI), purchasing manager's index (PMI), indeks harga konsumen (IHK/inflasi), dan indeks harga saham gabungan (IHSG). Jenis data yang digunakan adalah data sekunder yang didapatkan dari berbagai sumber yang relevan. Variabel yang diteliti dari tahun 2015-2020 dengan menggunakan data bulanan (time-series). Analisis hubungan kausalitas dalam konteks Granger-causality digunakan dalam penelitian ini untuk mengetahui apakah variabel yang diteliti mempunyai hubungan satu arah atau dua arah. Hal ini dimaksudkan bahwa dari variabel yang berhubungan memberitahu variabel mana yang menyebabkan variabel lain berubah. Dalam menentukan kesesuaian model diperlukan kondisi yang stasioner dengan menggunakan Augmented Dickey-Fuller $(A D F)$ test. Perlu dipastikan juga bahwa variabel yang diteliti stasioner pada level, first difference, atau second difference. Selanjutnya untuk dapat melakukan uji kointegrasi, perlu dipastikan bahwa variabel memiliki derajat integrasi yang sama atau tidak. Ketika variabel-variabel yang diteliti terintegrasi pada derajat yang berbeda, semisal variabel satu terintegrasi pada level (nol), variabel yang lain terintegrasi pada level pertama, maka variabel tersebut tidak terkointegrasi (mengindikasikan kurangnya hubungan jangka panjang antar variabel). Atas dasar itu, model Vector-Autoregressive (VAR) dalam standard Granger-causality perlu dilakukan untuk mengetahui hubungan jangka pendek seperti yang diformulasikan sebagai berikut:

$$
\begin{aligned}
& \Delta Y_{t}=\alpha+\sum_{i=1}^{\rho} \alpha y_{i} \Delta Y_{t-i}+\sum_{i=1}^{\rho} \alpha x_{i} \Delta X_{t-i}+\varepsilon_{t} \\
& \Delta X_{t}=\beta+\sum_{i=1}^{\rho} \beta x_{i} \Delta X_{t-i}+\sum_{i=1}^{\rho} \beta y_{i} \Delta Y_{t-i}+\mu_{t}
\end{aligned}
$$

$\mathrm{X}$ dan $\mathrm{Y}$ adalah variabel yang diamati, $\alpha$ dan $\beta$ sebagai konstanta vektor, $\rho$ sebagai panjang lag, $\alpha \mathrm{x}_{\mathrm{i}}, \beta \mathrm{x}_{\mathrm{i}}, \alpha \mathrm{y}_{\mathrm{i}}, \beta \mathrm{y}_{\mathrm{i}}$ sebagai koefisien matriks, serta $\varepsilon_{t}$ dan $\mu_{t}$ sebagai vektor pengganggu. Dua persamaan Vector-Autoregressive ini (1 dan 2) dapat diperluas menjadi persamaan multivariat dengan memasukkan lebih banyak variabel. Bisa kita lihat bahwa dalam Granger-causality test menunjukkan adanya pengaruh masa lalu terhadap kondisi saat ini (data time series). Selain Grangercausality test yang menjelaskan kausalitas jangka pendek, hubungan kausalitas jangka panjang muncul ketika ada kointegrasi antar variabel, dan setidaknya 
terdapat kausalitas satu arah (Granger, 1988). Ditemukannya kointegrasi pada variabel yang diamati akan mengikuti Vector Error-Correction Model (VECM) yang diformulasikan sebagai berikut:

$$
\begin{aligned}
& \Delta Y_{t}=\alpha+\sum_{i=1}^{\rho} \alpha y_{i} \Delta Y_{t-i}+\sum_{i=1}^{\rho} \alpha x_{i} \Delta X_{t-i}+\lambda E Y_{t-1}+\varepsilon_{t} \\
& \Delta X_{t}=\beta+\sum_{i=1}^{\rho} \beta x_{i} \Delta X_{t-i}+\sum_{i=1}^{\rho} \beta y_{i} \Delta Y_{t-i}+\gamma E X_{t-1}+\mu_{t}
\end{aligned}
$$

Model persamaan bivariate ini (3 dan 4) juga bisa dimodifikasi menjadi persamaan multivariate dengan menambahkan lebih banyak variabel. Dalam formula vector error-correction model tersebut, $\Delta \mathrm{X}$ dan $\Delta \mathrm{Y}$ adalah variabel stasioner pada first difference dan terkointegrasi, sedangkan $\mathrm{EY}_{\mathrm{t}-1}$ dan $\mathrm{EX}_{\mathrm{t}-1}$ adalah nilai lag dari error correction terms yang dijelaskan pada formula berikut:

$$
\begin{aligned}
& E Y_{t-1}=Y_{t}-v X_{t} \\
& E X_{t-1}=X_{t}-w Y_{t}
\end{aligned}
$$

\section{HASIL DAN PEMBAHASAN}

Pada bagian ini akan dijelaskan tahapan metode yang terbentuk dari variabel-variabel yang digunakan dalam penelitian ini. Sebelum pengujian model, diperlukan proses yang menguji apakah data stasioner pada level atau tidak, menemukan panjang lag optimal, uji kausalitas, uji kointegrasi, dan estimasi model.

\section{Uji Stasioner}

Pengujian akar-akar unit (unit root test) dilakukan untuk melihat apakah data stasioner atau tidak. Hasil pengujian menunjukkan bahwa data stasioner pada level first difference. Pada tabel 1 dapat dilihat bahwa nilai probabilitas lebih kecil dari nilai kritis 5\%, sehingga data telah stasioner dan digunakan dalam permodelan.

Tabel 1.

\section{Unit Root Test (First Difference)}

\begin{tabular}{lcl}
\hline Method & Statistic & Prob. \\
\hline Levin, Lin \& Chu t* & -15.0159 & 0.0000 \\
Im, Pesaran and Shin W-stat & -13.3413 & 0.0000 \\
ADF - Fisher Chi-square & 119.916 & 0.0000 \\
PP - Fisher Chi-square & 110.350 & 0.0000 \\
\hline \multicolumn{2}{c}{ Sumber: Hasil Output Eviews }
\end{tabular}




\section{Panjang Lag Optimal}

Penentuan lag akan dikaitkan dengan uji stasioneritas sebelumnya. Menentukan panjang lag yang optimal merupakan hal yang penting dalam permodelan agar model mampu mengestimasi actual error dengan tepat. Hasil diketahui bahwa lag optimal adalah lag 2 yang ditunjukkan oleh kriteria LR, FPE, AIC, SC, dan HQ.

\section{Tabel 2.}

\section{Panjang Lag Optimal}

\begin{tabular}{ccccccc}
\hline Lag & LogL & LR & FPE & AIC & SC & HQ \\
\hline 0 & -1033.778 & NA & $1.36 \mathrm{e}+08$ & 30.08051 & $30.21002^{*}$ & 30.13189 \\
1 & -1009.817 & 44.44845 & $1.08 \mathrm{e}+08$ & 29.84977 & 30.49734 & 30.10668 \\
2 & -985.2185 & $42.78008^{*}$ & $84732172 *$ & $29.60054^{*}$ & 30.76616 & $30.06298^{*}$ \\
\hline
\end{tabular}

\section{Sumber: Hasil Output Eviews}

\section{Uji Stabilitas}

Dalam uji stabilitas menunjukkan kondisi yang stabil, sehingga data mampu digunakan untuk melakukan variance decompotition dan IRF dapat digunakan untuk prediksi. Berikut hasil output dari uji stabilitas:

Tabel 3.

\section{Uji Stabilitas (Modulus)}

\begin{tabular}{lc}
\hline Root & Modulus \\
\hline $0.254269-0.642242 \mathrm{i}$ & 0.690744 \\
$0.254269+0.642242 \mathrm{i}$ & 0.690744 \\
-0.633373 & 0.633373 \\
$-0.045561-0.545040 \mathrm{i}$ & 0.546941 \\
$-0.045561+0.545040 \mathrm{i}$ & 0.546941 \\
0.445982 & 0.445982 \\
$-0.031625-0.105852 \mathrm{i}$ & 0.110475 \\
$-0.031625+0.105852 \mathrm{i}$ & 0.110475
\end{tabular}

VAR satisfies the stability condition Sumber: Hasil Output Eviews 
Inverse Roots of AR Characteristic Polynomial

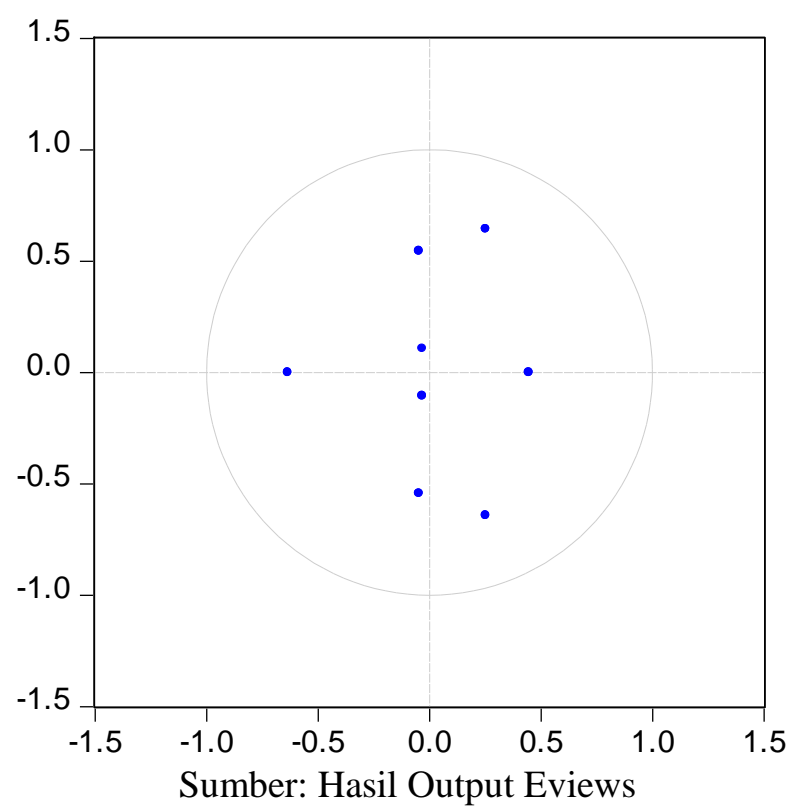

Gambar 3. Uji Stabilitas (dot-plot)

(No root lies outside the unit circle)

\section{Uji Kointegrasi}

Uji kointegrasi diperlukan untuk melihat adanya hubungan jangka panjang pada data. Dalam hal ini data dalam bentuk first difference yang digunakan dalam uji kointegrasi. Hasil estimasi menunjukkan bahwa terdapat hubungan kointegrasi sehingga VECM digunakan untuk mengetahui perilaku jangka pendek terhadap nilai jangka panjangnya.

Tabel 4.

\section{Uji Kointegrasi}

\begin{tabular}{ccccc}
\hline $\begin{array}{c}\text { Hypothesized } \\
\text { No. of CE(s) }\end{array}$ & Eigenvalue & $\begin{array}{c}\text { Trace } \\
\text { Statistic }\end{array}$ & $\begin{array}{c}\mathbf{0 . 0 5} \\
\text { Critical Value }\end{array}$ & Prob.** \\
\hline None $*$ & 0.757331 & 159.8093 & 47.85613 & 0.0000 \\
At most $1 *$ & 0.336877 & 63.51734 & 29.79707 & 0.0000 \\
At most 2 $*$ & 0.272507 & 35.58329 & 15.49471 & 0.0000 \\
At most 3 $*$ & 0.185461 & 13.94901 & 3.841466 & 0.0002 \\
\hline
\end{tabular}

Trace test indicates 4 cointegrating eqn(s) at the 0.05 level

$*$ denotes rejection of the hypothesis at the 0.05 level

**MacKinnon-Haug-Michelis (1999) p-values

Sumber: Hasil Output Eviews 


\section{Uji Kausalitas Granger}

Uji ini dilakukan untuk untuk melihat bagaimana hubungan antar variabel yang diteliti. Dalam tabel 5 menunjukkan bahwa hampir semua variabel mempunyai hubungan satu arah kecuali variabel CCI terhadap IHK dan sebaliknya.

Tabel 5.

\section{Uji Kausalitas Granger}

\begin{tabular}{lccc}
\hline Null Hypothesis: & Obs & F-Statistic & Prob. \\
\hline PMI does not Granger Cause IHSG & 70 & 8.89048 & 0.0004 \\
IHSG does not Granger Cause PMI & & 1.97334 & 0.1472 \\
& 70 & 6.83520 & 0.0020 \\
CCI does not Granger Cause IHSG & & 0.66683 & 0.5168 \\
IHSG does not Granger Cause CCI & 70 & 1.05480 & 0.3541 \\
& & 5.58690 & 0.0058 \\
IHK does not Granger Cause IHSG & 70 & 6.28921 & 0.0032 \\
IHSG does not Granger Cause IHK & & 12.6690 & $2 . \mathrm{E}-05$ \\
CCI does not Granger Cause PMI & 70 & 7.01682 & 0.0017 \\
PMI does not Granger Cause CCI & & 2.13270 & 0.1267 \\
& & & \\
IHK does not Granger Cause PMI & 70 & 0.35139 & 0.7050 \\
PMI does not Granger Cause IHK & & 11.3981 & $6 . \mathrm{E}-05$ \\
\hline IHK does not Granger Cause CCI & & & \\
CCI does not Granger Cause IHK & & & \\
\hline
\end{tabular}

Hasil uji kausalitas granger diketahui: (1) Terdapat hubungan satu arah PMI terhadap IHSG. Hal ini menunjukkan bahwa optimisme dunia bisnis yang ditunjukkan oleh aktivitas sektor manufaktur dapat memicu pergerakan pasar modal (IHSG). (2) Terdapat hubungan satu arah CCI terhadap IHSG. Fakta ini menunjukkan bahwa indeks keyakinan konsumen yang mencerminkan perilaku mikro konsumen berdampak pada kondisi pasar modal. Konsumen akan menyesuaikan perilaku konsumsi dan investasi berdasarkan kondisi perekonomian. (3) Terdapat hubungan satu arah IHSG terhadap IHK. Pergerakan pasar modal mencerminkan nilai saham dan tingkat pengembaliannya. Naik turunnya nilai suatu saham akan menentukan batasan aktivitas ekonomi yang terjadi, semisal nilai kekayaan dari saham tersebut yang berpengaruh pada aktivitas konsumsi atau kasus saham sebagai jaminan. (4) Terdapat hubungan satu arah CCI terhadap PMI. Seperti yang dijelaskan sebelumnya bahwa indeks keyakinan konsumen mencerminkan perilaku mikro konsumen. Ketika nilai indeks meningkat, menunjukkan optimisme terhadap kondisi perekonomian dimasa depan. Hal tersebut tentu akan menggairahkan dunia bisnis akibat naiknya jumlah permintaan. (5) Terdapat hubungan satu arah IHK terhadap PMI. Masih dalam kasus yang sama dengan 
sebelumnya, bahwa tingkat inflasi akan menjadi indikator apakah tingkat konsumsi sedang mengalami kontraksi atau tidak. Ketika tingkat inflasi tertekan memberi sinyal bahwa perekonomian sedang mengalami kelesuan. Dunia usaha akan mengurangi aktivitas bisnisnya karena jumlah permintaan yang menurun.

\section{Estimasi VECM}

Hasil pengujian sebelumnya yang menunjukkan adanya hubungan kointegrasi menghasilkan estimasi VECM yang dijabarkan dalam persamaan berikut:

$\mathrm{D}(\mathrm{CCI})=0.0010611484942 *(\mathrm{IHSG}(-1)-1169.86782199 * \mathrm{PMI}(-1)-112.30764745$

$* \mathrm{CCI}(-1)+134.348528758 * \mathrm{IHK}(-1)+47477.6482008)+0.00313718302794$

$* \mathrm{D}(\mathrm{IHSG}(-1))+0.0054375872608 * \mathrm{D}(\mathrm{IHSG}(-2))+1.13189951102 * \mathrm{D}(\mathrm{PMI}(-1))$

$+0.5765908932 * \mathrm{D}(\mathrm{PMI}(-2))-0.288492445558 * \mathrm{D}(\mathrm{CCI}(-1))-0.353225972607$

*D(CCI(-2)) - 0.0794797007338*D(IHK(-1)) - $0.199095882352 * \mathrm{D}(\mathrm{IHK}(-2))$

$+1.00688122186$

\section{Tabel 6.}

Hasil Estimasi VECM (Long-Term)

\begin{tabular}{cc}
\hline Cointegrating Eq: & CointEq1 \\
\hline CCI(-1) & 1.000000 \\
& 10.41664 \\
PMI(-1) & {$[5.64952]$} \\
& -1.196255 \\
IHK(-1) & {$[-1.82469]$} \\
& -0.008904 \\
IHSG(-1) & {$[-1.00644]$} \\
& -422.7464 \\
\hline
\end{tabular}

Sumber: Hasil Output Eviews 
Tabel 7.

Hasil Estimasi VECM (Short-Term)

\begin{tabular}{ccccc}
\hline Error Correction: & $\mathbf{D}(\mathbf{C C I})$ & $\mathbf{D}(\mathbf{P M I})$ & $\mathbf{D}(\mathbf{I H K})$ & $\mathbf{D}(\mathbf{I H S G})$ \\
\hline CointEq1 & -0.119175 & -0.035172 & -0.012780 & -1.884865 \\
& {$[-6.73823]$} & {$[-2.95382]$} & {$[-0.76509]$} & {$[-2.17192]$} \\
D(CCI(-1)) & -0.288492 & 0.016167 & 0.079545 & 5.046694 \\
& {$[-2.32335]$} & {$[0.19339]$} & {$[0.67829]$} & {$[0.82831]$} \\
D(CCI(-2)) & -0.353226 & -0.113812 & -0.230875 & -10.62302 \\
& {$[-2.76724]$} & {$[-1.32437]$} & {$[-1.91510]$} & {$[-1.69608]$} \\
D(PMI(-1)) & 1.131900 & 0.538660 & -0.156503 & 39.79067 \\
& {$[4.50549]$} & {$[3.18475]$} & {$[-0.65960]$} & {$[3.22790]$} \\
D(PMI(-2)) & 0.576591 & -0.119035 & 0.522349 & 31.90324 \\
& {$[2.11469]$} & {$[-0.64845]$} & {$[2.02844]$} & {$[2.38461]$} \\
D(IHK(-1)) & -0.079480 & -0.069423 & -0.129986 & -8.276443 \\
& {$[-0.66327]$} & {$[-0.86052]$} & {$[-1.14856]$} & {$[-1.40762]$} \\
D(IHK(-2)) & -0.199096 & 0.010362 & -0.068193 & 6.544790 \\
& {$[-1.71969]$} & {$[0.13294]$} & {$[-0.62367]$} & {$[1.15209]$} \\
D(IHSG(-1)) & 0.003137 & 0.001488 & 0.002694 & 0.025504 \\
& {$[1.20255]$} & {$[0.84702]$} & {$[1.09353]$} & {$[0.19924]$} \\
D(IHSG(-2)) & 0.005438 & 0.000201 & 0.009293 & 0.137788 \\
& {$[2.41071]$} & {$[0.13252]$} & {$[4.36230]$} & {$[1.24496]$} \\
& 1.006881 & 0.069000 & 0.371277 & 8.800174 \\
& C & {$[0.21847]$} & {$[0.83799]$} & {$[0.38231]$} \\
\hline & & &
\end{tabular}

Sumber: Hasil Output Eviews

Hasil estimasi menunjukkan bahwa dalam jangka panjang terdapat pola hubungan positif CCI dengan dirinya sendiri. Kemudian PMI menunjukkan pola hubungan positif, sedangkan IHK dan IHSG menunjukkan hubungan negatif. Hanya variabel PMI yang memberikan pengaruh signifikan terhadap CCI dalam jangka panjang. Dalam jangka pendek, PMI mempunyai pola hubungan positif dan memberikan pengaruh signifikan terhadap CCI dan IHSG pada lag 1 dan 2, serta memberikan pengaruh signifikan terhadap IHK pada lag 2. Sejalan dengan penelitian yang dilakukan oleh Zorio-Grima dan Merello (2020), bahwa sentimen bisnis dan indeks saham mempunyai hubungan dengan consumer confidence. 
Møller et al. (2014) dalam penelitiannya juga memaparkan bahwa consumer confidence dan siklus bisnis mempunyai korelasi positif, dan keduanya mempengaruhi return saham. Juhro dan lyke (2019) dalam penelitiannya ditunjukkan bahwa peran tingkat kepercayaan dan sentimen terhadap konsumsi dan siklus bisnis mempunyai implikasi yang penting dalam meningkatkan public/market confidence. IHSG mempunyai pola hubungan positif dan signifikan terhadap CCI dan IHK pada lag 2. Kolluri dan Wahab (2008), Asmy, Rohilina, Hassama, dan Fouad (2010), Bai dan Green (2011), Alam (2017), Antonakakis et al. (2017) juga melaporkan dalam penelitiannya yang menunjukkan hubungan positif antara inflasi dan harga saham.

\section{KESIMPULAN}

Penelitian ini membahas bagaimana hubungan antara sentimen bisnis dan konsumen, tingkat inflasi, serta indeks harga saham. Berdasarkan hasil uji kausalitas, didapatkan hasil bahwa hampir semua variabel menunjukkan hubungan satu arah, yaitu antara PMI terhadap IHSG, CCI terhadap IHSG, IHSG terhadap IHK, CCI terhadap PMI, IHK terhadap PMI. Sedangkan hasil estimasi VECM dalam jangka panjang menyatakan bahwa terdapat pola hubungan positif CCI dengan dirinya sendiri. Kemudian PMI menunjukkan pola hubungan positif, sedangkan IHK dan IHSG menunjukkan hubungan negatif. Hanya variabel PMI yang memberikan pengaruh signifikan terhadap CCI dalam jangka panjang. Lalu dalam jangka pendek, PMI mempunyai pola hubungan positif dan memberikan pengaruh signifikan terhadap CCI dan IHSG pada lag 1 dan 2, serta memberikan pengaruh signifikan terhadap IHK pada lag 2. IHSG mempunyai pola hubungan positif dan signifikan terhadap CCI dan IHK pada lag 2.

Dari keseluruhan hasil pengujian, dapat disimpulkan bahwa banyak keterkaitan antar variabel yang diteliti, sehingga dapat dikatakan optimisme dari sudut pandang dunia usaha dan konsumen perlu dijaga oleh para pemangku kepentingan khususnya pemerintah dan bank sentral. Perlunya kebijakan fiskal dan moneter yang mampu merespon dengan cepat dalam menjaga tingkat kepercayaan masyarakat terhadap perekonomian, sehingga ketika adanya kontraksi ekonomi, tidak menimbulkan efek lesu yang berkepanjangan. Pemerintah dan bank sentral harus mampu mereduksi kepanikan pasar dan membangun tingkat kepercayaan masyarakat sehingga tingkat inflasi tetap terkendali dan sesuai target. Hal ini dikarenakan situasi pasar modal sangat sensitif dengan adanya kondisi tersebut. Penelitian ini masih belum membahas perilaku dinamis dari model VECM melalui respon setiap variabel terhadap shock variabel yang lain dan melakukan peramalan bagaimana respon dari suatu variabel dimasa yang akan datang jika terjadi shock pada variabel lainnya. 


\section{DAFTAR PUSTAKA}

Akbar, M., Ali, S., \& Khan, M. F. (2011). The relationship of stock prices and macroeconomic variables revisited: Evidence from Karachi stock exchange. African Journal of Business Management, 6(4). https://doi.org/10.5897/ajbm11.1043

Al-shami, H. A. A., \& Ibrahim, Y. (2013). The effect of macroeconomic indicators on stock returns evidence of Kuwait Stock Market. American Journal of Economics, 3(2009), 57-66. https://doi.org/10.5923/c.economics.201301.11

Alam, N. (2017). Analysis of the impact of select macroeconomic variables on the indian stock market: A heteroscedastic cointegration approach. Business and Economic Horizons, 13(1), 119-127. https://doi.org/10.15208/beh.2017.09

Antonakakis, N., Gupta, R., \& Tiwari, A. K. (2017). Has the correlation of inflation and stock prices changed in the United States over the last two centuries? Research in International Business and Finance, 42, 1-8. https://doi.org/10.1016/j.ribaf.2017.04.005

Asmy, M., Rohilina, W., Hassama, A., \& And, M. (2010). Effects of Macroeconomic Variables on Stock Prices in Malaysia: An Approach of Error Correction Model. MPRA Munich Personal Repec Archive, 20970.

Bai, Y., \& Green, C. J. (2011). Determinants of cross-sectional stock return variations in emerging markets. Empirical Economics, 41(1), 81-102. https://doi.org/10.1007/s00181-010-0437-9

Balcilar, M., Cakan, E., \& Gupta, R. (2017). Does US news impact Asian emerging markets? Evidence from nonparametric causality-in-quantiles test. North American Journal of Economics and Finance, 41, 32-43. https://doi.org/10.1016/j.najef.2017.03.009

Berge, T. J., \& Jordà, Ò. (2011). Evaluating the classification of economic activity into recessions and expansions. American Economic Journal: Macroeconomics, 3(2), 246-277. https://doi.org/10.1257/mac.3.2.246

Bock, D. E., Eastman, J. K., \& McKay, B. (2014). The impact of economic perceptions on status consumption: An exploratory study of the moderating role of education. Journal of Consumer Marketing, 31(2), 111-117. https://doi.org/10.1108/JCM-10-2013-0725

Dees, S. (2017). The role of confidence shocks in business cycles and their global dimension. International Economics, 151(September 2011), 4865. https://doi.org/10.1016/j.inteco.2017.03.004 
Ferrer, E., Salaber, J., \& Zalewska, A. (2016). Consumer confidence indices and stock markets' meltdowns. European Journal of Finance, 22(3), 195-220. https://doi.org/10.1080/1351847X.2014.963634

Granger, C. W. J. (1988). Some recent development in a concept of causality. Journal of Econometrics, 39(1-2), 199-211. https://doi.org/10.1016/0304-4076(88)90045-0

Iyke, B. N., \& Ho, S. Y. (2020). Consumption and exchange rate uncertainty: Evidence from selected Asian countries. World Economy, 43(9), 24372462. https://doi.org/10.1111/twec. 12900

Joseph, A., Larrain, M., \& Turner, C. (2011). Forecasting purchasing managers' index with compressed interest rates and past values. Procedia Computer Science, 6, 213-218. https://doi.org/10.1016/j.procs.2011.08.040

Juhro, S. M. (2015). The Role of the Central Bank in Promoting Sustainable Growth: Perspectives on the Implementation of Flexible ITF in Indonesia. Afro Eurasian Studies Journal, 4(1), 23-61.

Juhro, S. M., \& Iyke, B. N. (2019). Consumer confidence and consumption expenditure in Indonesia. Economic Modelling, 89(September), 367377. https://doi.org/10.1016/j.econmod.2019.11.001

Kilic, E., \& Cankaya, S. (2016). Consumer confidence and economic activity: a factor augmented VAR approach. Applied Economics, 48(32), 3062-3080. https://doi.org/10.1080/00036846.2015.1133902

Kolluri, B., \& Wahab, M. (2008). Stock returns and expected inflation: Evidence from an asymmetric test specification. Review of Quantitative Finance and Accounting, 30(4), 371-395. https://doi.org/10.1007/s11156-007-0060-9

Konstantinou, P., \& Tagkalakis, A. (2011). Boosting confidence: Is there a role for fiscal policy? Economic Modelling, 28(4), 1629-1641. https://doi.org/10.1016/j.econmod.2011.02.019

Li, H., Guo, Y., \& Park, S. Y. (2017). Asymmetric Relationship between Investors' Sentiment and Stock Returns: Evidence from a Quantile Non-causality Test. International Review of Finance, 17(4), 617-626. https://doi.org/10.1111/irfi.12120

Møller, S. V., Nørholm, H., \& Rangvid, J. (2014). Consumer confidence or the business cycle: What matters more for European expected returns? Journal of Empirical Finance, 28, 230-248. https://doi.org/10.1016/j.jempfin.2014.07.004

Naik, P. K., \& Padhi, P. (2012). The impact of Macroeconomic Fundamentals on Stock Prices revisited: An Evidence from Indian Data. Eurasian Journal of Business and Economics, 5(10), 25-44. 
Neely, C. J., \& Dey, S. R. (2010). A survey of announcement effects on foreign exchange returns. Federal Reserve Bank of St. Louis Review, 92(5), 417-445. https://doi.org/10.20955/r.92.417-64

Ozyildirim, A., Schaitkin, B., \& Zarnowitz, V. (2010). Business cycles in the euro area defined with coincident economic indicators and predicted with leading economic indicators. Journal of Forecasting, 29(1-2), 628. https://doi.org/10.1002/for.1146

Salhin, A., Sherif, M., \& Jones, E. (2016). Managerial sentiment, consumer confidence and sector returns. International Review of Financial Analysis, 47, 24-38. https://doi.org/10.1016/j.irfa.2016.06.009

Sorić, P. (2018). Consumer confidence as a GDP determinant in New EU Member States: a view from a time-varying perspective. Empirica, 45(2), 261-282. https://doi.org/10.1007/s10663-016-9360-4

Suhaibu, I., Harvey, S. K., \& Amidu, M. (2017). The impact of monetary policy on stock market performance: Evidence from twelve (12) African countries. Research in International Business and Finance, 42(12), 1372-1382. https://doi.org/10.1016/j.ribaf.2017.07.075

Zorio-Grima, A., \& Merello, P. (2020). Consumer confidence: Causality links with subjective and objective information sources. Technological Forecasting and Social Change, 150(June 2019), 119760. https://doi.org/10.1016/j.techfore.2019.119760 